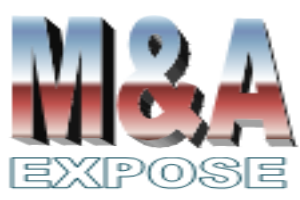

http://jurnal.usahid.ac.id/index .php/accounting
${ }^{1}$ Fakultas Ekonomi dan Bisnis

Universitas Sahid Jakarta dewi.anggraini20081974@gmail.com trieshandrimaniamain@gmail.com

\section{Kajian Faktor-Faktor yang Mempengaruhi Laba Bank Perkreditan Rakyat Syariah Di DKI Jakarta}

\author{
Dewi Anggraini ${ }^{1}$, Tries Handriman Jamain ${ }^{1}$
}

\section{Abstrak}

Penelitian ini bertujuan untuk mengetahui faktor-faktor yang mempengaruhi laba Bank Pembiayaan Rakyat Syariah di DKI Jakarta. Dalam penelitian ini digunakan data sekunder berupa laporan keuangan Bank Pembiayaan Rakyat Syariah tahun 20112015. Variabel dependen adalah aspek profitabilitas yang diukur dengan ROA (Return On Assets), sedangkan variabel independen terdiri dari rasio permodalan yang diukur dengan rasio CAR (Capital Adequacy Ratio), rasio kualitas aset produktif yang diukur dengan rasio NPF (Non Performing Financing), rasio efisiensi yang diukur dengan rasio BOPO (Biaya Operasional Pendapatan Operasional), dan rasio likuiditas yang diukur dengan rasio FDR (Financing to Deposit Ratio). Hasil penelitian menunjukkan secara parsial variabel CAR dan FDR tidak berpengaruh signifikan terhadap ROA, namun variabel NPF dan BOPO secara parsial berpengaruh signifikan terhadap ROA. Adapun secara simultan variabel CAR, NPF, BOPO dan FDR berpengaruh signifikan terhadap ROA.

Kata kunci : CAR, NPF, BOPO, FDR, ROA.

\section{Abstract}

This study aims to determine the factors that influence the profits of Sharia Financing Banks in DKI Jakarta. In this study secondary data is used in the form of financial statements of the Sharia Financing Bank for 2011-2015. The dependent variable is the aspect of profitability as measured by ROA (Return On Assets), while the independent variable consists of the capital ratio measured by the CAR (Capital Adequacy Ratio) ratio, the quality ratio of productive assets as measured by the NPF (Non Performing Financing) ratio, efficiency ratio which is measured by the BOPO ratio (Operational Income Operating Cost), and the liquidity ratio measured by the FDR (Financing to Deposit Ratio) ratio. The results showed partially that the $C A R$ and FDR variables did not significantly influence ROA, but the NPF and BOPO variables partially had a significant effect on ROA. The simultaneous variables CAR, NPF, BOPO and FDR have a significant effect on ROA.

Keywords : CAR, NPF, BOPO, FDR, ROA. 


\section{PENDAHULUAN}

Menurut Undang-Undang Nomor 10 Tahun 1998 tentang Perbankan, bank adalah badan usaha yang menghimpun dana dari masyarakat dalam bentuk simpanan dan menyalurkannya kepada masyarakat dalam bentuk kredit dan atau bentuk-bentuk lainnya dalam rangka meningkatkan taraf hidup rakyat banyak. Bank berfungsi sebagai lembaga intermediasi keuangan antara pihak yang memiliki kelebihan dana dengan pihak yang memerlukan dana. Bank menghimpun dana dari pihak yang kelebihan dana dalam bentuk tabungan, deposito dan giro. Kegiatan penyaluran dana kepada masyarakat dalam bentuk pemberian kredit atau pembiayaan.

Pemerintah memberi perhatian besar terhadap pengembangan sektor usaha menengah, kecil dan mikro (UMKM). Kondisi ini mengharuskan setiap pengusaha UMKM melakukan upaya menstabilkan atau meningkatkan eksistensi usahanya. Masalah yang umum dihadapi UMKM adalah masalah permodalan. Bank pemerintah maupun bank swasta berusaha memberikan kredit bagi usaha UMKM. Lembaga keuangan yang tepat dan strategis untuk melayani kebutuhan UMKM adalah bank mikro yang dikenal dengan nama Bank Perkreditan Rakyat (BPR) baik yang beroperasi dengan sistem konvensional maupun syariah, yang dikenal dengan nama Bank Pembiayaan Rakyat Syariah (BPRS).

Salah satu indikator penting untuk menilai kinerja manajemen suatu bank adalah dengan mencermati laba yang dihasilkan oleh bank tersebut pada periode tertentu. Informasi laba secara umum menjadi perhatian utama dalam menaksir kinerja atau pertanggungjawaban manajemen dan membantu melakukan penaksiran atas kekuatan laba perusahaan di masa yang akan datang. Return on Assets (ROA) sebagai salah satu indikator profitabilitas mengindikasikan kemampuan perusahaan dalam memperoleh laba dengan memanfaatkan aktiva yang dimilikinya.

Sebelumnya terdapat beberapa penelitian yang dilakukan untuk melihat berbagai faktor yang mempengaruhi laba pada industri perbankan di Indonesia. Faktor-faktor internal seperti likuiditas, efisiensi, modal, pembiayaan yang disalurkan, tingkat nisbah yang diberikan, resiko pembiayaan, kepemilikan saham maupun factor eksternal seperti tingkat suku bunga, nilai kurs, struktur pasar, indeks harga saham gabungan .Dari kedua faktor itu, hanya faktor internal yang dapat dikendalikan oleh perusahaan perbankan sedangkan faktor eksternal adalah faktor yang tidak dapat dikendalikan oleh perusahaan.

Dari penelitian-penelitian faktor internal yang telah dilakukan terdapat perbedaan hasil penelitian antara satu peneliti dengan peneliti lainnya dan juga terdapat perbedaan antara teori dengan hasil penelitian yang telah dilakukan. Selain itu berbeda daerah penelitian juga berbeda hasil penelitian.

Penelitian ini dilakukan terhadap BPRS di DKI Jakarta. Dengan adanya penelitian ini maka diharapkan akan diketahui faktor yang mempengaruhi laba BPRS di DKI Jakarta sehingga dapat dijadikan dasar bagi pihak-pihak yang berkepentingan untuk meningkatkan kinerja BPRS. Dengan demikian diharapkan fungsi BPRS sebagai penopang UMKM dapat ditingkatkan. Tujuan penelitian adalah untuk mengetahui sejauh mana faktor-faktor modal (Capital Adequacy Ratio/CAR), kualitas asset produktif (Non Performing Financing/NPF), efisiensi (Biaya Operasional Pendapatan Operasional/BOPO), likuiditas (Financing to Deposit Ratio/FDR) secara simultan dan parsial berpengaruh terhadap laba pada BPRS di DKI Jakarta. 
Kajian Faktor-Faktor yang Mempengaruhi ...

Dewi Anggraini, Tries Handriman Jamain

\section{TINJAUAN PUSTAKA}

Laba. Harahap (2011) mendefinisikan laba akuntansi sebagai perbedaan antara realisasi penghasilan yang berasal dari transaksi perusahaan pada periode tertentu dikurangi dengan biaya yang dikeluarkan untuk mendapatkan penghasilan itu. Menurut Nafarin (2009), laba adalah perbedaan antara pendapatan dengan keseimbangan biayabiaya dan pengeluaran untuk periode tertentu. Perusahaan akan memperoleh keuntungan apabila penghasilan yang diperoleh lebih besar daripada beban yang dikeluarkan, dan dinyatakan rugi apabila sebaliknya.

Pencapaian laba merupakan indikator yang dominan dalam menilai kinerja operasional sebuah bank. Return On Asset (ROA) merupakan salah satu rasio profitabilitas yang digunakan untuk mengukur efektivitas perusahaan dalam menghasilkan keuntungan dengan memanfaatkan total aktiva yang dimilikinya. Semakin besar ROA menunjukkan kinerja perusahaan semakin baik, karena return semakin besar. Secara matematis ROA dirumuskan sebagai berikut :

$$
\text { ROA }=\frac{\text { Laba Sebelum Pajak }}{\text { Total Aktiva }} \times 100 \%
$$

Capital Adequacy Ratio (CAR). Capital Adequacy Ratio (CAR) adalah rasio yang digunakan untuk mengukur kemampuan bank dalam mempertahankan modal yang mencukupi dan kemampuan bank dalam mengidentifikasi, mengukur, mengawasi, dan mengontrol risiko yang dapat berpengaruh terhadap besarnya modal bank. Dengan kata lain CAR adalah rasio kinerja bank untuk mengukur kecukupan modal yang dimiliki bank untuk menunjang aktiva yang mengandung atau menghasilkan risiko, misalnya pembiayaan (Ismail, 2011).

Bank Indonesia menetapkan ketentuan modal minimum bagi perbankan sebagaimana ketentuan dalam standar Bank for International Settlements (BIS) bahwa setiap bank diwajibkan menyediakan modal minimum sebesar 8 persen dari total Aktiva Tertimbang Menurut Risiko (ATMR). Modal bank terdiri dari modal inti dan modal pelengkap. Modal inti adalah modal yang berasal dari para pemilik bank, yang terdiri dari modal yang disetor para pemegang saham, cadangan dan laba ditahan. Sedangkan modal pelengkap terdiri dari cadangan revaluasi aktiva tetap, penyisihan penghapusan aktiva produktif, modal pinjaman, dan pinjaman subordinasi.

Semakin tinggi CAR menunjukkan semakin baik kondisi suatu bank. Jika nilai CAR tinggi berarti bank tersebut mampu membiayai operasi bank, dan berkontribusi cukup besar bagi profitabilitas. Besarnya nilai CAR dirumuskan :

$$
\text { CAR }=\frac{\text { Total Modal }}{\text { Aktiva Tertimbang Menurut Resiko }} \times 100 \%
$$

Non Performing Financing (NPF). Non Performing Financing (NPF) adalah rasio yang digunakan untuk mengukur kemampuan manajemen bank dalam mengelola pembiayaan bermasalah (Setiawan, 2009). Pembiayaan dalam hal ini adalah pembiayaan yang diberikan kepada pihak ketiga dan tidak termasuk pembiayaan kepada bank lain. Sedangkan pembiayaan bermasalah adalah pembiayaan dengan kualitas kurang lancar, diragukan, dan macet. NPF berpengaruh negatif terhadap profitabilitas perbankan. Semakin 
tinggi NPF, semakin menurun kinerja atau profitabilitas perbankan. Adapun nilai NPF dapat dirumuskan :

$$
\mathrm{NPF}=\frac{\text { Pembiayaan Bermasalah }}{\text { Total Pembiayaan }} \times 100 \%
$$

Biaya Operasional Pendapatan Operasional (BOPO). Biaya Operasional Pendapatan Operasional (BOPO) adalah rasio perbandingan biaya operasional dan pendapatan operasional. Rasio ini d mengukur tingkat efisiensi dan kemampuan bank dalam melakukan kegiatan operasi (Dendawijaya, 2005). Semakin rendah BOPO menunjukkan semakin efisien bank mengendalikan biaya operasionalnya sehingga keuntungan semakin besar. Nilai BOPO dirumuskan :

$$
\text { BOPO }=\frac{\text { Biaya Operasional }}{\text { Pendapatan Operasional }} \times 100 \%
$$

Financing to Deposit Ratio (FDR). Financing to Deposit Ratio (FDR) merupakan rasio yang digunakan untuk mengukur likuiditas bank dalam membayar kembali penarikan dana yang dilakukan deposan (Ismail, 2011). Semakin tinggi FDR maka semakin tinggi dana yang disalurkan ke pihak ketiga. Dengan penyaluran dana pihak ketiga yang besar maka pendapatan bank akan semakin meningkat, sehingga keuntungan juga akan semakin meningkat. Nilai FDR dirumuskan :

$$
\text { FDR }=\frac{\text { Pembiayaan yang Diberikan }}{\text { Total Dana Pihak Ketiga }} \times 100 \%
$$

Penelitian Terdahulu. Berikut beberapa penelitian terdahulu tentang berbagai faktor yang berpengaruh terhadap laba perbankan :

1. Mulyati (2015) menyimpulkan bahwa DPK, FDR dan BOPO bank umum syariah yang terdaftar di Bursa Efek Indonesia berpengaruh negatif terhadap ROA, sedangkan NPF dan SWBI berpengaruh positif terhadap ROA.

2. Agustini (2014) menyimpulkan bahwa CAR dan LDR Bank Perkreditan Rakyat di Kabupaten Badung berpengaruh positif terhadap ROA, sedangkan NPL berpengaruh negatif terhadap ROA.

3. Yusuf (2016) menyimpulkan bahwa pembiayaan, DPK, FDR, NPF di Bank Pembiayaan Rakyat Syariah (BPRS) di Aceh signifikan terhadap ROA.

4. Heriyanto (2009) menyimpulkan bahwa CAR, NIM pada bank pemerintah di Indonesia berpengaruh positif signifikan terhadap ROA, sedangkan NPL dan BOPO berpengaruh negatif signifikan terhadap ROA. Adapun LDR dan KAP tidak berpengaruh terhadap ROA.

5. Kamal (2014) menyimpulkan bahwa CAR pada Bank Pembiayaan Rakyat Syariah di Indonesia Pasca Krisis Keuangan Global berpengaruh signifikan terhadap ROA, sedangkan FDR, NPF dan BOPO tidak berpengaruh terhadap ROA. 
6. Muhaemin (2016) menyimpulkan bahwa CAR dan FDR pada Bank Pembiayaan Rakyat Syariah di Indonesia berpengaruh positif terhadap ROA, sedangkan NPF berpengaruh negatif terhadap ROA.

Penelitian terdahulu menunjukkan perbedaan temuan penelitian dan juga perbedaan antara teori dengan beberapa simpulan penelitian. Adapun perbedaan penelitian ini dengan penelitian terdahulu adalah bahwa penelitian ini berfokus pada Bank Pembiayaan Rakyat Syariah (BPRS) di DKI Jakarta.

Hipotesis Penelitian. Berdasarkan latar belakang dan tinjauan pustaka, dirumuskan hipotesis penelitian ini sebagai berikut :

1. Capital Adequacy Ratio (CAR) berpengaruh signifikan terhadap laba (ROA).

2. Non Performing Financing (NPF) berpengaruh signifikan terhadap laba (ROA).

3. Biaya Operasional Pendapatan Operasional (BOPO) berpengaruh signifikan terhadap laba (ROA).

4. Financing to Deposit Ratio (FDR) berpengaruh signifikan terhadap laba (ROA).

5. Capital Adequacy Ratio (CAR), Non Performing Financing (NPF), Biaya Operasional Pendapatan Operasional (BOPO), dan Financing to Deposit Ratio (FDR) secara simultan berpengaruh terhadap laba (ROA).

\section{METODE PENELITIAN}

Penelitian ini mengambil objek penelitian semua Bank Pembiayaan Rakyat Syariah (BPRS) yang ada di DKI Jakarta. Jumlah Bank Pembiayaan Rakyat Syariah yang ada di DKI Jakarta adalah 2 BPRS yaitu PT. BPRS Hidayah di Jl. Kresek Raya No. 18B Duri Kosambi Jakarta Barat dan PT. BPRS Cempaka Al Amin di Jl. Ulujami Raya No. 10C Jakarta Selatan.

Data yang digunakan adalah data kuantitatif. Dalam penelitian ini, digunakan data sekunder berupa laporan keuangan triwulan Bank Pembiayaan Rakyat Syariah (BPRS) di DKI Jakarta tahun 2011-2015 yang dipublikasikan di website Bank Indonesia.

Metode analisis data yang digunakan dalam penelitian ini adalah regresi linear berganda yaitu suatu model linear regresi yang variabel dependennya merupakan fungsi linear dari beberapa variabel bebas. Persamaan regresi yang digunakan adalah sebagai berikut :

$$
\begin{aligned}
& \mathrm{Y}=\mathrm{a}+\mathrm{b}_{1} \mathrm{X}_{1}+\mathrm{b}_{2} \mathrm{X}_{2}+\mathrm{b}_{3} \mathrm{X}_{3}+\mathrm{b}_{4} \mathrm{X}_{4}+\mathrm{e} \\
& \text { Keterangan: } \\
& \mathrm{Y} \quad=\text { Return On Asset (ROA) } \\
& \mathrm{a} \quad=\text { konstanta } \\
& \mathrm{X}_{1} \quad=\text { Capital Adequacy Ratio (CAR) } \\
& \mathrm{X}_{2} \quad=\text { Non Performing Financing (NPF) } \\
& \mathrm{X}_{3} \quad=\text { Biaya Operasional Pendapatan Operasional (BOPO) } \\
& \mathrm{X}_{4} \quad=\text { Financing to Deposit Ratio (FDR) }
\end{aligned}
$$

\section{HASIL DAN PEMBAHASAN}

Statistik Deskriptif. Analisis statistik deskriptif menunjukkan nilai minimum, nilai maksimum, rata-rata, dan standar deviasi masing-masing variabel sebagaimana Tabel 1. 


\begin{tabular}{crrrrr}
\multicolumn{7}{c}{ Tabel 1. Statistik Deskriptif } \\
\hline N & \multicolumn{1}{c}{ Minimum } & Maximum & \multicolumn{1}{c}{ Mean } & \multicolumn{1}{c}{ Std. Deviation } \\
\hline CAR & 16 &,- 0600 &, 1700 &, 029813 &, 0588265 \\
NPF & 16 &, 0900 &, 2600 &, 178750 &, 0398121 \\
BOPO & 16 &, 0800 &, 3800 &, 220000 &, 0990623 \\
FDR & 16 &, 6000 & 2,6800 & 1,128750 &, 5271922 \\
Valid N (listwise) & 16 &, 5500 &, 9700 &, 833125 &, 1040332 \\
\hline
\end{tabular}

Sumber : data diolah.

Uji Asumsi Klasik. Uji asumsi klasik dilakukan agar model yang terbentuk memberikan estimasi yang Best Linier Unbiased Estimated (BLUE). Uji normalitas dengan uji Kolmogrof-Smirnov pada Tabel 2 berikut menunjukkan nilai signifikansi sebesar 0,087. Jadi model regresi berdistribusi normal karena tingkat signifikansinya lebih dari 0,05.

Tabel 2. Uji Normalitas

\begin{tabular}{|c|c|c|}
\hline & & Unstandardized Residual \\
\hline$\overline{\mathrm{N}}$ & & 16 \\
\hline Normal Parameters ${ }^{a, b}$ & Mean & ,0000000 \\
\hline & Std. Deviation & ,03193861 \\
\hline Most Extreme & Absolute & 200 \\
\hline Differences & Positive & 200 \\
\hline & Negative &,- 152 \\
\hline Test Statistic & & ,200 \\
\hline Asymp. Sig. (2-tailed) & &, $087^{\circ}$ \\
\hline
\end{tabular}

Uji multikolinieritas pada Tabel 3 berikut menunjukkan seluruh variabel independen mempunyai nilai VIF kurang dari batas maksimal 10,00 dan nilai tolerance lebih dari 0,10. Dengan demikian semua variabel independen tidak menunjukkan adanya gejala kolinieritas, jadi distribusi data tidak mengalami multikolinieritas.

Tabel 3. Uji Multikolinieritas

\begin{tabular}{crr}
\hline \multirow{2}{*}{ Model } & \multicolumn{2}{c}{ Collinearity Statistics } \\
\cline { 2 - 3 } & Tolerance & \multicolumn{1}{c}{ VIF } \\
\hline CAR &, 689 & 1,451 \\
NPF &, 616 & 1,623 \\
BOPO &, 429 & 2,329 \\
FDR &, 518 & 1,932 \\
\hline
\end{tabular}

Sumber : data diolah.

Uji heteroskedastisitas dengan Uji Glejser pada Tabel 4 berikut menunjukkan bahwa seluruh variabel independen memiliki nilai signifikansi lebih besar dari 0,05 sehingga dapat disimpulkan bahwa tidak terjadi heteroskedastisitas dalam model penelitian ini. 
Kajian Faktor-Faktor yang Mempengaruhi ... Dewi Anggraini, Tries Handriman Jamain

Tabel 4. Uji Heteroskedastisitas

\begin{tabular}{crrrrr}
\hline \multirow{2}{*}{ Model } & \multicolumn{2}{c}{$\begin{array}{l}\text { Unstandardized } \\
\text { Coefficiens }\end{array}$} & $\begin{array}{c}\text { Standardized } \\
\text { Coefficiens }\end{array}$ & \multirow{2}{*}{$\mathrm{t}$} & \multirow{2}{*}{ Sig. } \\
\cline { 2 - 4 } & \multicolumn{1}{c}{$\mathrm{B}$} & \multicolumn{1}{c}{ Std. Error } & \multicolumn{1}{c}{ Beta } & & \\
\hline (Constant) &, 132 &, 061 & & 2,172 &, 053 \\
CAR &, 030 &, 143 &, 062 &, 212 &, 836 \\
NPF &,- 129 &, 061 &,- 661 & $-2,133$ &, 056 \\
BOPO &, 010 &, 014 &, 283 &, 762 &, 462 \\
FDR &,- 115 &, 063 &,- 618 & $-1,827$ &, 095 \\
\hline Dependent Variable : RES2. & & & \\
Sumber : data diolah. & & &
\end{tabular}

Uji autokorelasi menggunakan run test sebagaimana Tabel 5 berikutnya menunjukkan nilai signifikansi $>0,05$ sehingga dapat disimpulkan bahwa data tidak memiliki gejala autokorelasi.

Tabel 5. Uji Autokorelasi

\begin{tabular}{lr}
\hline & Unstandardized Residual \\
\hline Test Value &,- 01351 \\
Cases $<$ Test Value & 8 \\
Cases $>=$ Test Value & 8 \\
Total Cases & 16 \\
Number of Runs & 9 \\
Z &, 000 \\
Asymp. Sig. (2-tailed) & 1,000 \\
\hline a. Median & \\
Sumber : data diolah. &
\end{tabular}

Analisis Regresi Liner Berganda. Selanjutkan setelah model bebas masalah asumsi klasik, maka dilakukan analisis regresi liner berganda sebagaimana Tabel 6 berikut :

Tabel 6. Analisis Regresi Berganda

\begin{tabular}{crrr}
\hline \multirow{2}{*}{ Model } & \multicolumn{2}{c}{$\begin{array}{c}\text { Unstandardized } \\
\text { Coefficiens }\end{array}$} & $\begin{array}{c}\text { Standardized } \\
\text { Coefficiens }\end{array}$ \\
\cline { 2 - 4 } & \multicolumn{1}{c}{$\mathrm{B}$} & \multicolumn{1}{c}{ Std. Error } & \multicolumn{1}{c}{ Beta } \\
\hline (Constant) &, 145 &, 124 & \\
CAR &, 093 &, 291 &, 063 \\
NPF &,- 274 &, 124 &,- 462 \\
BOPO &,- 062 &, 028 &,- 552 \\
FDR &,- 002 &, 129 &,- 004 \\
\hline Dependent : ROA. & &
\end{tabular}

Sumber : data diolah.

Berdasarkan tabel 6 , diperoleh persamaan regresi linier berganda sebagai berikut :

$\mathrm{Y}=0,145+0,093 \mathrm{CAR}-0,274 \mathrm{NPF}-0,062 \mathrm{BOPO}-0,002$ FDR

Persamaan tersebut mengindikasikan hubungan antara variabel dependen dan independen sebagai berikut :

1. Variabel CAR berpengaruh positif terhadap ROA. Koefisien CAR sebesar 0,093 menunjukkan bahwa setiap peningkatan CAR satu satuan, maka akan meningkatkan ROA sebesar 0,093 dengan asumsi variabel independen lainnya konstan. Jika nilai CAR meningkat, maka BPRS memiliki peluang yang cukup besar untuk melakukan 
pembiayaan atau BPRS mampu untuk menanggung risiko dari setiap aktiva produktif sehingga mampu membiayai operasi bank yang akan mendorong peningkatan ROA.

2. Variabel NPF berpengaruh negatif terhadap ROA. Koefisien NPF sebesar $-0,274$ menunjukkan bahwa setiap peningkatan NPF satu satuan, maka akan menurunkan ROA sebesar 0,274 dengan asumsi variabel independen lainnya konstan. Nilai NPF yang negatif mengindikasikan bahwa ketika terjadi peningkatan NPF maka akan menurunkan perolehan ROA. NPF merupakan indikator pembiayaan bermasalah. Keberadaan pembiayaan bermasalah menandakan bahwa pembiayaan yang disalurkan mengalami kesulitan dalam penerimaan penagihannya yang berdampak pada beban operasional bank dan pada dana pihak ketiga. Semakin tinggi pembiayaan bermasalah maka akan meningkatkan beban operasional dan berdampak pada penurunan pendapatan. Peningkatan NPF akan mengakibatkan likuiditas BPRS menjadi tersendat karena BPRS kesulitan untuk menyalurkan kembali dana yang dimilikinya karena dana yang dimilikinya tersebut macet. Hal ini akan mengakibatkan terjadinya penurunan ROA.

3. Variabel BOPO berpengaruh negatif terhadap ROA. Koefisien BOPO sebesar $-0,062$ menunjukkan bahwa setiap peningkatan BOPO satu satuan, maka akan menurunkan ROA sebesar 0,062 dengan asumsi variabel independen lainnya konstan. Nilai BOPO yang negatif mengindikasikan bahwa ketika terjadi peningkatan BOPO, maka pihak BPRS masih belum efisien dalam menjalankan operasionalnya. Nilai BOPO yang meningkat menunjukkan bahwa biaya operasional BPRS meningkat atau pendapatan operasional BPRS menurun. Apabila hal ini terjadi maka akan mengakibatkan terjadi penurunan ROA.

4. Variabel FDR berpengaruh negatif terhadap ROA. Koefisien FDR sebesar $-0,002$ menunjukkan bahwa setiap peningkatan FDR satu satuan, maka akan menurunkan ROA sebesar 0,002 dengan asumsi variabel independen lainnya konstan. Kondisi FDR yang besar dalam satu periode tidak secara langsung berkontribusi terhadap kenaikan ROA pada periode yang sama. Hal ini disebabkan tingkat kelancaran penerimaan pembiayaan yang diberikan. Tingginya penyaluran dana yang diberikan BPRS, akan mengakibatkan terjadinya penurunan ROA yang diperoleh apabila BPRS tidak mampu menyalurkan pembiayaan dengan efektif.

Uji Hipotesis Parsial. Uji t digunakan untuk mengukur pengaruh variabel-variabel independen secara parsial terhadap variabel dependen. Apabila nilai probabilitas lebih kecil dari 0,05 maka variabel independen secara parsial berpengaruh signifikan terhadap variabel dependen.

Tabel 7. Uji t

\begin{tabular}{|c|c|c|c|c|c|}
\hline \multirow[t]{2}{*}{ Model } & \multicolumn{2}{|c|}{$\begin{array}{c}\text { Unstandardized } \\
\text { Coefficiens }\end{array}$} & \multirow{2}{*}{$\begin{array}{c}\text { Standardized } \\
\text { Coefficiens } \\
\text { Beta }\end{array}$} & \multirow[t]{2}{*}{$\mathrm{t}$} & \multirow[t]{2}{*}{ Sig. } \\
\hline & $B$ & Std. Error & & & \\
\hline (Constant) & ,145 & ,124 & & 1,171 & ,266 \\
\hline CAR & ,093 & 291 & ,063 & ,318 & ,756 \\
\hline NPF &,- 274 & ,124 &,- 462 & $-2,214$ & ,049 \\
\hline BOPO &,- 062 & ,028 &,- 552 & $-2,210$ & ,049 \\
\hline FDR & -,002 & ,129 &,- 004 &,- 019 & 985 \\
\hline
\end{tabular}


Tabel 7 tersebut mengindikasikan bahwa hanya variabel NPF dan BOPO yang nilai signifikansinya lebih kecil daripada 0,05. Dengan demikian hanya variabel NPF dan BOPO yang berpengaruh signifikan terhadap ROA. Adapun variabel CAR dan FDR tidak berpengaruh signifikan terhadap ROA.

Uji Hipotesis Simultan. Uji F dilakukan untuk mengetahui pengaruh semua variabel independen secara simultan terhadap variabel dependen. Apabila nilai probabilitas lebih kecil dari 0,05 maka semua variabel independen secara simultan berpengaruh signifikan terhadap variabel dependen.

Tabel 8. Uji F

\begin{tabular}{rrrrrrr}
\hline & Model & Sum of Squares & Df & Mean Square & $F$ & Sig. \\
\hline 1 & Regression &, 037 & 4 &, 009 & 6,579 &, $006^{\mathrm{b}}$ \\
& Residual &, 015 & 11 &, 001 & & \\
& Total &, 052 & 15 & & & \\
\hline
\end{tabular}

a. Dependent Variable: ROA

b. Predictors: (Constant), FDR, CAR, NPF, BOPO

Sumber : data diolah.

Tabel 8 tersebut mengindikasikan bahwa nilai $\mathrm{F}$ memiliki nilai signifikansi lebih kecil daripada 0,05 . Dengan demikian seluruh variabel independen secara simultan berpengaruh signifikan terhadap ROA.

Koefisien Determinasi. Koefisien determinasi menganalisis kemampuan model dalam menjelaskan, menerangkan dan mengilustrasikan variasi variabel dependen. Tabel 9 menunjukkan nilai Adjust $R$ Square sebesar 0,598, yang bermakna bahwa variabel independen dalam model penelitian ini (CAR, NPF, BOPO, FDR) mampu menjelaskan dan menggambarkan variasi variable dependen (ROA) sebesar $59,8 \%$, sedangkan sisanya sebesar $40,2 \%$ dijelaskan oleh faktor-faktor lain di luar model penelitian ini.

Tabel 9. Koefisien Determinasi $\left(R^{2}\right)$

\begin{tabular}{crrrr}
\hline Model & $\mathrm{R}$ & $\mathrm{R}$ Square & Adjusted R Square & $\begin{array}{c}\text { Std. Error of the } \\
\text { Estimate }\end{array}$ \\
\hline 1 &, $840^{\mathrm{a}}$ &, 705 &, 598 &, 0372963 \\
\hline
\end{tabular}

a. Predictors: (Constant), FDR, CAR, NPF, BOPO

b. Dependent Variable: ROA

Sumber : data diolah.

\section{KESIMPULAN}

Berdasarkan analisis dan pembahasan tentang faktor-faktor yang mempengaruhi laba pada BPRS di DKI Jakarta, maka dapat disimpulkan bahwa hanya variabel NPF dan BOPO yang berpengaruh signifikan terhadap ROA. Adapun variabel CAR dan FDR tidak berpengaruh signifikan terhadap ROA. Namun seluruh variabel independen secara simultan berpengaruh signifikan terhadap ROA.

Kesimpulan tersebut berimplikasi bahwa BPRS di DKI Jakarta harus terus meningkatkan pengelolaannya agar memperoleh laba yang maksimal seperti yang ditargetkan. Hal ini dimaksudkan karena BPRS sangat berperan dalam pemberdayaan golongan UMKM. Sejalan dengan hal tersebut, BPRS harus melakukan pengawasan lebih 
ketat terhadap pembiayaan yang disalurkan. Hal ini dimaksudkan untuk meningkatkan prinsip kehati-hatian sehingga dapat meminimalkan Non Performing Financing. Penelitian mendatang dapat menambahkan variabel-variabel independen lainnya yang tidak dibahas dalam penelitian ini serta memperluas sampel yang lebih luas dengan menambah data tidak hanya dari BPRS tetapi juga bank umum syariah atau unit syariah sehingga dapat mewakili keseluruhan populasi bank syariah.

\section{DAFTAR PUSTAKA}

Muhaemin, Ahmad. 2016. Analisis Faktor-faktor Yang Memengaruhi Profitabilitas Bank Pembiayaan Rakyat Syariah di Indonesia. Jurnal Nisbah. Vol. 2, No. 1. Institut Pertanian Bogor.

Bank Indonesia. 2016. Surat Edaran Bank Indonesia No. 9/29/DPBS.

Bank Indonesia. 2009. PBI No 11/23/PBI/2009 Tentang Bank Pembiayaan Rakyat Syariah.

Dendawijaya L. 2005. Manajemen Perbankan. Bogor : Ghalia Indonesia.

Kamal, Fasiha. 2014. Analisis Faktor-faktor Yang Mempengaruhi Profitabilitas Bank Pembiayaan Rakyat Syariah di Indonesia Pasca Krisis Keuangan Global Tahun 2008. Jurnal Muamalat. Vol. IV, No. 1, STAIN Palopo.

Harahap, Syofyan Syafri. 2011. Teori Akuntansi. Jakarta : Rajawali Pers.

Ismail AK, 2011. Manajemen Perbankan : Dari Teori Menuju Aplikasi. Jakarta : Kencana.

Hanania, Luthfia. 2015. Faktor Internal dan Eksternal Yang Mempengaruhi Profitabilitas Perbankan Syariah Dalam Jangka Pendek dan Jangka Panjang. Perbanas Review. Vol. I, No. 1. Perbanas Institute.

Yusuf, Muhammad Yasir. 2016. Faktor-faktor Yang Mempengaruhi Tingkat Profitabilitas Bank Pembiayaan Rakyat Syariah di Aceh. Jurnal lqtishadia. Vol. 9. No. 2. UIN ArRaniry Banda Aceh.

Nafarin. 2009. Penganggaran Perusahaan. Jakarta : Salemba Empat.

Undang-Undang RI No.10 Tahun 1998. Perubahan Atas Undang-Undang No.7 Tahun 1992 Tentang Perbankan. Jakarta.

Agustini, Si Luh Anik Sri. 2014. Analisis Faktor-faktor yang memengaruhi Profitabilitas Bank Perkreditan Rakyat di Kabupaten Badung. E-Jurnal Akuntansi Universitas Udayana.

Muliawati, Sri. 2015. Faktor-faktor Penentu Profitabilitas Bank Syariah di Indonesia. Management Analysis Journal. Universitas Negeri Semarang.

Setiawan A. 2009. Analisis Pengaruh Faktor Makroekonomi, Pangsa Pasar dan Karakteristik Bank terhadap Profitabilitas Bank Syariah. Tesis. Semarang : Universitas Diponegoro. 